Senegalese migrants' children, homeland returns, and Islamic education in a transnational setting

\author{
Hannah Hoechner \\ School of International Development, University of East Anglia, Norwich, UK \\ h.hoechner@uea.ac.uk
}

Word count: 8,094 


\title{
Senegalese migrants' children, homeland returns, and Islamic education in a transnational setting
}

\begin{abstract}
Homeland visits and stays have only recently began to receive attention within the growing literature on the religious beliefs and practices of 'second generation' Muslims in Western contexts, just as African Muslims have largely been neglected within this emerging field. Drawing on data collected over a total of 14 months among Senegalese migrant communities in the greater New York area, and in Islamic schools receiving migrants' children in Dakar, Senegal, this paper outlines how young people's homeland returns for the sake of religious education give rise to complex negotiations of meaning and identity.
\end{abstract}

Keywords: return migration, Muslim youth, second generation, Islamic education, West Africa

\section{Introduction}

"You're not gonna be in hell for eternity, right?"

"Mohammed [the prophet], did he speak English or French?"

"Was Adam black or white?"

"On the day of judgement, will you be naked?"

Oustaz Ly, ${ }^{1}$ who is teaching Islamic Studies to the middle and high school students at IQRA Bilingual Academy, a recently founded English-French bilingual Islamic school in Dakar, Senegal, very rarely manages to teach all of what he set out to teach during his lesson, be it the pillars of faith, the intricacies of praying correctly, or the rules of performing ablutions. Too numerous are

\footnotetext{
${ }^{1}$ I have changed or removed the names of respondents where I felt it necessary to protect their identity.
} 
the questions with which his students keep side-tracking him, and he usually strives to answer them carefully.

Some of the students' questions reveal issues that preoccupy them during their daily lives outside of the Islamic studies classroom: mastering different languages (including English and French) is one such issue; having a particular skin colour is another. Other questions bespeak a genuine religious curiosity and even degree of anxiety, as the one on the amount of time a sinner will likely spend in hell. A final set of questions - like the one on being naked on the day of judgement - are mostly asked to raise laughs in the class (in this case successfully) and result in complaints on the part of teachers about the unruliness and irreverence of some of the 'returnee' students at the school.

About a third of the students at IQRA Bilingual Academy weren't born and raised in Senegal but have been sent 'back' ${ }^{2}$ to their parents' homeland in their late childhood or early adolescence from various places, including prominently the United States, but also France, Belgium and Italy. In many cases, the parents hope that a stint in a religious school in Senegal will protect their children from the unbelief and social decay they encounter in the deprived inner-city environments of their American, or European, homes. Drawing on data collected over a total of 14 months among Senegalese migrant communities in the greater New York area, and in Islamic schools receiving migrants' children in Dakar, Senegal, this paper explores how young people experience such 'returns', shedding light specifically on the religious dimensions of these experiences. The next section situates this paper in the literature. I outline debates on so-called

\footnotetext{
${ }^{2}$ King and Christou $(2011,456)$ write aptly that '[i]n many respects, second-generation returnees are first-generation immigrants in their homelands'. Being sent 'back' can mean for some children going to a country they have never been to and that they know only indirectly from their parents' tales, or phone calls with relatives there.
} 
'second generation' Muslim youths in the West and how the links between their 'return' mobilities, sense of belonging and religious orientations have been discussed.

\section{Muslim youths and 'return' mobilities}

The religious practices and beliefs of 'second generation' Muslims in the West have become the object of intense scrutiny in recent decades as politicians and the general public have tried to come to grips with acts of terror committed by members of this so-called 'second generation'. Yet, as Bozorgmehr and Kasinitz $(2018 b, 4)$ rightly point out, 'the disproportionate focus on a fringe extremist minority has obscured the experiences of the vast majority of Muslim youth.' These experiences have begun to receive more scholarly attention recently. Researchers have sought to understand for example how young Muslims navigate the often divergent expectations of their families and of wider society, and how an increasingly hostile social and political environment affects their religious identities and sense of belonging (Bozorgmehr and Kasinitz 2018a; Haddad, Senzai, and Smith 2009; Levitt, Barnett, and Khalil 2011; Levitt, Lucken, et Barnett 2011; Rytter 2010; Zine 2008).

A persistent concern for researchers has been to understand differences in religious beliefs and practices among the 'first' and 'second' generations. Some authors have observed a trend towards greater 'orthodoxy' and stricter interpretations of Islam among 'second generation' youths, juxtaposed with declining religious adherence (e.g. Timmerman et al. 2003; Voas and Fleischmann 2012) or a 'consumer' approach to Islam, with young people 'choosing which rules and tenets of their religion to embrace and which to dismiss' (Cesari 2002, 41). However, recent research with transnationally mobile young people urges us to treat categories such as 'first' and 'second' generation with caution. Such categories assign great importance to a person's place of 
birth and first international move, neglecting the impact of further moves both within and across countries (van Geel and Mazzucato 2018, 2145). Alas, these moves may have an important impact on young people's trajectories (ibid, see also Zeitlyn 2015, 68).

How do young people's connections to their 'homeland' relate to their religious identities and practices? Some authors have claimed that close and continued ties with the 'homeland' serve to smoothen the transmission of religious identities and doctrinal orientations across generations and transnational space. This argument has been made particularly to account for the fact that some Muslim diasporas appear to show greater 'immunity' to 'radical' forms of Islam than others (see Lesthaeghe 2002 in Levitt 2003, 852-3, with respect to Turkish versus Moroccan youths in Belgium; see Babou n.d. with respect to West African diasporas).

However, recent research paying closer attention to the perspectives and experiences of transnationally mobile young Muslims themselves suggests a more complicated picture, as homeland visits/stays affect the ways in which young people position themselves vis-à-vis this 'homeland', the societies they grew up in, as well as their religion in complex ways (Bolognani 2014; Erdal et al. 2016; Reisel, Bredal, and Lidén 2018; Zeitlyn 2015). Existing studies of young Muslims' transnational mobility caution us against assuming that homeland visits/stays necessarily bring young people closer to the religious beliefs and practices of their parents. Zeitlyn $(2015,141)$ and Bolognani (2014) for example both note how the British-raised Bangladeshi and Pakistani youths in their respective researches came to regard the Islam practiced in their 'homelands' as culturally tainted and inferior to their own version of it (see also Reisel, Bredal, and Lidén 2018, 166). According to Bolognani, such views allowed her participants to upgrade their own social position in Pakistan (Bolognani 2013, 114-5). This highlights the importance of paying attention to the wider social dynamics of 'homeland' visits. 
Several scholars emphasise how 'homeland' visits/stays can give rise to ambivalent feelings as young people are taken out of their habitual environment and must learn a new 'habitus' (Zeitlyn 2015; see also Tiilikainen 2011; Abotsi, n.d.; Sancho 2018 in this special issue). Zeitlyn $(2015,136)$ describes how such ambivalence led some young British-Bangladeshi in his research 'towards religion as a source of identity and certainty' and away from nationally/ethnically defined identities. The young Norwegians of Pakistani and Somali heritage in Reisel et al.'s $(2018,168)$ research, who visited their 'homelands' for religious education, conversely, returned to Norway with greater appreciation for Norwegian society and culture after having acquired a point of comparison. These observations chime with the wider recognition in the literature on migrant transnationalism that 'returns' do not inevitably strengthen migrants' identification with their 'homelands'. 'Returnees' may discover that their homelands are different from what they expected, or have changed during their absence, and that they feel 'out of place' where they expected to feel home (e.g. Oeppen 2013, 271; see also Carling and Pettersen 2014).

This paper adds to the debates outlined here by exploring the experiences of young people who are sent 'back' to Senegal, highlighting how stints in Islamic schools there do not automatically produce the 'educated persons' (Levinson and Holland, 1996) ${ }^{3}$ desired by teachers and parents, but give rise to complex negotiations of meaning and identity, in which young people mobilise frames of reference of various origins (cf. Levitt, Lucken, and Barnett 2011, 468). Coming to terms with an unfamiliar social and cultural environment and disciplinary regime in

\footnotetext{
${ }^{3}$ Levinson and Holland $(1996,2)$ propose this notion to refer to the often contested, constantly renegotiated 'set of criteria by which members [of a given society] can be identified as more, or less, knowledgeable'. This paper uses it broadly to shed light onto competing ideas about desirable behavior and appropriate strategies for inculcating it.
} 
Senegal is central to the experiences of the young people in this paper, highlighting the importance of the wider social dynamics of homeland returns.

What is more, when young people 'return' to Senegal, they rarely encounter life and religion exactly as their migrant parents left them behind at the time they emigrated. Over the past few decades, new types of Islamic schools have popped up, prospered, and expanded. Some of these schools have explicitly sought to attract migrants' children, and some have succeeded so much at this that they have turned into veritable 'little Americas'. This paper explores some of these new developments, which parallel trends observed in other parts of the world that have received significant numbers of return migrants (e.g. Erdal et al. 2016 on Pakistan; Lindley 2008, on Somalia). Erdal et al. $(2016,842)$ describe how residential segregation and demand for private English language schools among returnees in Pakistan 'complicat[es] the picture of what kind of Pakistan they return to'. This paper describes how young Senegalese-Americans 'return' to places and practices that have emerged in Senegal only relatively recently and partly due to transnational migration, complicating the idea that homeland returns produce intergenerational continuity.

By shedding light on the experiences of young Muslims of sub-Saharan African origin and the dynamics surrounding their returns, the paper complements existing studies of Muslim youths, which have mostly focused on South Asian, Middle Eastern and North African communities. This is true both for studies focusing on processes of religious identity formation and Islamic education in Western settings (Bozorgmehr and Kasinitz 2018a; Haddad, Senzai, and Smith 2009; Mandaville 2007; Zine 2008) and for those exploring such processes in the context of transnational mobility (Bolognani 2014; Erdal et al. 2016; Reisel, Bredal, and Lidén 2018; Zeitlyn 2015). In the West African context, a growing number of authors study transnational child-rearing practices, documenting migrant parents' decisions to send children to the homeland for 'disciplining', to 
protect them from what are considered to be the morally corrupting or outright physically dangerous influences of Western society (Abotsi 2018; Bledsoe and Sow 2011; Coe and Shani 2015; Kea and Maier 2017; Timera 2002), to prevent school failure (see Dia 2016 on children sent from France to Senegal) or finally to free up their time to work (see Coe 2014 on Ghanaian migrants in the US; see Grysole 2018 on Senegalese migrants in the US and Italy). Religious motivations for sending children back have received relatively little attention within this body of literature, even though migrants from several West African countries including Senegal, the Gambia, Mauritania, Guinea and Mali are known to send their children back to their home country for the sake of religious education (Kane 2011; Kea 2016; Razy 2006). What is more, most authors prioritise the perspectives of parents and pay limited attention to young people's own views on return (for a notable exception, see Abotsi 2018). This paper complements the existing literature by focussing specifically on the religious dimensions of return and on young people's own experiences.

The next section describes data and research context. I then explore the Senegalese case, outlining how living in a Western setting (New York and New Jersey) has heightened demands for religious education among Senegalese migrant parents who hope that Islamic knowledge will help protect their children against the presumed evils of Western society, or, conversely, bring them back to the 'straight and narrow'. The second part of the paper explores young people's participation in, and experiences of, the Islamic education sector in Senegal, challenging narratives equating homeland returns with intergenerational continuity in the transmission of religious identities, and with it the smooth production of one particular type of 'educated person'. 


\section{Data and research context}

The data for this paper were collected during seven months of fieldwork carried out in Dakar, the capital of Senegal, which is a 95\% Muslim country, between 2014 and 2016, and during seven months of fieldwork carried out in New York and adjacent New Jersey in the United States in 2017 and 2018. I collected data in the form of ethnographic fieldwork observations in different schools (including Islamic schools) in both Senegal and the US, where I interviewed headmasters, teachers and students. I also collected data more widely through semi-structured interviews, group conversations and casual interactions with Senegalese migrants and their children in non-school settings in both Senegal and the US. I chose New York/New Jersey as fieldwork locations since 'New Yorkers' were well represented among the sent back children and youths I met in Senegal, and because the greater New York area is a hub for Senegalese migrants in the US.

While I gained access to Islamic schools and to returnees relatively easily in Senegal, conditions in the US were more challenging. As a white, non-Muslim woman, I struggled to win the trust of Senegalese migrants in a context where surveillance of Muslim communities has sharply increased since $9 / 11$, making people weary of outside enquirers. The current political climate under the Trump Administration has exacerbated fears, especially among unauthorised migrants, of government crackdowns and deportation. Given the heightened scrutiny to which immigrant parents are submitted by child protection agencies, people are cautious to not reveal potentially compromising information to outsiders. My German nationality, familiarity with Senegal and with Islamic education (I studied Qur'anic schools in northern Nigeria for my PhD), and knowledge of French and Wolof (Senegal's lingua franca) could only do so much to allay people's fears. Winning their trust became possible only through long-term engagement with the community (including by living in two Senegalese households in Harlem and the Bronx for the 
duration of my fieldwork) and upon repeated intercession on my behalf by trusted members of the community. Most interviews with young people were conducted in English, which they felt most comfortable in, though some switched into Wolof occasionally. Interviews with parents were conducted both in English, French, and Wolof (with occasional help from a friend acting as translator).

\section{Parents' ideals of the 'educated person' and transnational childrearing}

Many Senegalese parents share certain expectations about how children ought to be/behave, often with the implicit assumption that these expectations conform to Islamic norms. Respect for elders is a central value they hope to instil, alongside a sense of responsibility for others, especially family members, and a commitment to discipline and hard work (cf. Abotsi n.d. in this special issue). Parents also expect their children to take their religious practice - notably their daily prayers seriously, to adopt a 'decent' dress code and demeanour, ${ }^{4}$ and to stay away from comportments considered problematic and un-Islamic, including premarital sex (especially for girls), same-sex relationships, and the consumption of drugs and alcohol. Many parents believe that studying the Qur'an, and the Islamic religion more broadly, will help strengthen their children's commitment to these norms, echoing Ware's (2014) emphasis on Qur'anic learning as ultimately aiming not merely at knowledge acquisition but at personal transformation, through imitating the

\footnotetext{
${ }^{4}$ For girls, this mostly means dressing and behaving modestly. For boys, notions of appropriate dress and demeanour are more fluid, even though I encountered frequent and fierce opposition to American youth fashion styles, notably trousers worn 'down', letting the underwear show.
} 
comportment of the teacher. One mother in New York, who had sent her son to a Qur'anic school in Senegal, summarised the importance for learning the Qur'an as follows:

with the Qur'an, you can't be a bad person. Maybe if someone learned the Qur'an and come back [from Senegal] being bad boy or bad girl [sic], sooner or later, he's gonna come back in the right path. Because the Qur'an does something ...

There are a number of full-time private Islamic schools in New York and adjacent New Jersey, yet they are mostly too costly for Senegalese families, especially if they have to cater to several children. ${ }^{5}$ Many children attend weekend Qur'anic schools. However, many parents find the training they provide cannot counterbalance the wider influences their children are exposed to, and feel unable to transmit, let alone enforce, the behavioural norms they seek to instil. The participants in my research found themselves weighed down with various social and economic pressures, including frequent divorces, ${ }^{6}$ busy work schedules limiting the time they could spend with their children, and high rent prices, which often confined them to socially deprived inner-city neighbourhoods. In this context, parents worried that they could not sufficiently protect their daughters' sexuality, and that their sons may drift off into gang violence, drugs, and delinquency. Parents feel unable to ensure that children acquire the requisite religious knowledge to withstand

${ }^{5}$ Private full-time Islamic schools mostly charge fees of $400 \$$ minimum per month. While flights to Senegal are also costly (a return flight from New York to Dakar costs around 1,000\$), general living costs are significantly lower in Senegal, and fees in most Islamic schools are below $100 \$$ per month (upmarket bilingual schools charge almost as much as US-based schools though).

${ }^{6}$ Marriages are extremely fragile in a context where both spouses work long hours outside the home. This triggers conflicts about the distribution of domestic chores, and about financial responsibility for the household budget (see Kane 2011, 167ff for an extensive discussion of the renegotiation of gender roles and the resulting marital conflicts among Senegalese couples in New York). 
these perceived risks, but they also feel barred from exerting the strict discipline (including physical punishments) they believe necessary to keep children on the right track. One of the mothers I was close to in New York, for example, criticised American child protection policies in stark terms, arguing that barring parents from disciplining their children when they are young puts these at risk of suffering the full force of the (racist) carceral state later in life:

the thing that makes me so mad is that you're telling them [the children] now that it's abuse, but down the line, if they start doing stuff, you're putting them in jail! Isn't that abuse too? You don't want nobody to correct them while they're young, when it can be done, and then when they become something else, when they're adults or young adults, you're ready to put them in jail. That's not right! ... I feel like they're sacrificing our children.

The combination of the factors outlined here motivates a significant number of migrants in the US to send their children back to Senegal at one point or another. Some migrants' children spend all their childhood and youth in Senegal and move to the US only for high school or tertiary education, or to start work. Others spend only their early childhood (ca. 2-5 years) in Senegal, usually looked after by grandparents or other family members when their care is particularly burdensome for their parents in the US given busy work schedules and the high costs of professional childcare. Other children leave the US when they are old enough to be accepted into a Qur'anic boarding school, usually around age six or seven, and return to the US one or several years later after having acquired some knowledge of the Qur'an. Another frequent practice is to send young people, especially boys, back to Senegal at the beginning of adolescence for disciplining or to get them out of trouble. Finally, children may visit Senegal during their summer holidays, and take classes with an oustaz (Qur'anic teacher), or enrol in a Qur'anic school, for the duration of their stay. 
While my research in Senegal focused mostly on young people enrolled in Qur'anic boarding schools and on young people sent back in early adolescence, in my research in the US, I also interviewed young people who had spent most of their childhood and youth in Senegal and returned to the US only for middle or high school. This paper focusses in particular on the experiences of young people who grew up mostly in the US but went to Senegal in late childhood and early adolescence (when aged 8-14 years). Although the paper draws on the experiences of all my respondents, much of the interview material cited stems from interviews with male youths (1417 years) who had been sent back to Senegal for 'disciplining' and who made up a big share of the 'returnee' population in the schools I studied.

\section{Young returnees' participation in the Islamic education sector}

Migrant parents have come to rely on a broad array of Islamic educational institutions in Senegal, ranging from summer Qur'an programmes or enrolment in local Qur'anic schools during the summer vacation, to stints of several months or years in a Qur'anic boarding school, to enrolment for several years or even entire school careers in a so-called French-Arabic school (école francoarabe) or in one of the recently founded, diaspora-oriented English-French 'bilingual' Islamic schools. Besides these more institutionalised settings, young people sent back to Senegal also learn about Islam from Qur'anic teachers (oustaz) who come to teach them at home, and from observing and participating in the everyday routines of their relatives, neighbours, and peers in a predominantly Muslim environment. Parents thus choose among a wide variety of different arrangements, and it is beyond the scope of this paper to explore all of them in detail. The remainder of this section will highlight that to some extent, migrants have been looking for particular setups for educating their children in Senegal. This in turn has left traces on the Islamic 
education sector (cf. Erdal et al. 2016; Lindley 2018; Sancho, this special issue, on comparable dynamics in other contexts).

Importantly, many migrant parents are acutely aware that in order to be successful one day within American society, their children need to become 'educated persons' not only proficient in religious knowledge and appropriate comportment, but also with a solid secular education and good English language skills (cf. Erdal et al. 2016, 842, who describe how returnee parents in Pakistan emphasise the importance of tarbyiat or moral instruction for their children while simultaneously 'do[ing] what they can to also secure the best possible formal education' for them). This has meant that both 'intensive' Qur'an programmes - which seek to instil Islamic knowledge (and notably knowledge of the Qur'an) into children quickly - and English-French bilingual Islamic schools - which teach Islamic knowledge, while simultaneously making sure that students are prepared for eventual reintegration into the American education system - have gained great popularity among migrant parents. One of my respondents, for example, explained her own reasoning about sending her son to a Qur'anic boarding school in Senegal for a year in the following way:

[sending them back will] put dine [religion] in them fast ... in a year, you have [memorised] half of the [Qur'an], you're done, and then they can go back to an American school.

'Modern' Qur'anic boarding schools (daara moderne), which focus exclusively on Qur'anic memorisation, while taking care of children's basic needs in terms of food and hygiene, are currently an up-and-coming business in Senegal. While such schools are popular of course not only among migrant parents but also among many local 'middle class' parents (who can afford the 30,000-60,000 FCFA per month, ca. 50-100\$, for room and board), I have met significant numbers 
of migrants' children (up to a quarter of students) in very much all the slightly more comfortable Qur'anic boarding schools I visited in Dakar.

Another noteworthy development relating to young returnees indicated above is the opening of English-French bilingual Islamic schools. As I develop in more details elsewhere (see Hoechner 2017), over the past decade, several English-French bilingual Islamic day schools have opened in Dakar, offering both religious instruction and an English-French bilingual curriculum. Such schools are sought after by better-off transnationally oriented Senegalese families who expect their children to acquire a 'cosmopolitan' education and learn English in anticipation of future mobility. Migrants are another primary target group of these schools. In the bilingual Islamic school I studied closely, about a third of the school's almost 300 students were foreign-born children who had either moved back to Senegal with their parents, or had been sent back on their own to stay there with family members. The majority of teachers were themselves either Senegalese return migrants (often coming back from North America), or international migrants (including from Anglophone parts of Africa and from the US). As one can imagine, the environment of this school is very different from 'typical' Senegalese Islamic schools, with English (rather than the local language Wolof) dominating schoolyard conversations, and students - rather than copying quietly from the blackboard - interrupting their Deenyat (Islamic studies) teacher repeatedly with questions about anything and everything, not stopping short even of apparently irreverent questions such as whether one would be naked on the Day of Judgement (see beginning of this paper).

While these newer setups exist of course alongside more 'classical' / time-honoured Islamic educational institutions, I highlight them here to draw attention to the fact that the Islamic education sector is highly dynamic, and responds to changing social conditions, including 
transnational migration. The institutions in which migrants' children find themselves are likely to be significantly different from those in which their parents once studied, which cautions against hasty conclusions about the neat intergenerational or transnational reproduction of a particular type of 'educated person'. The next section further corroborates this argument by exploring the experiences of young people who have travelled back to Senegal in their late childhood or teenage years. I met most of them in the bilingual Islamic day school just described; but I also draw on data collected in a Qur'anic boarding school in the suburbs of Dakar and among youths who had returned to the US after having spent some time in Senegal. All these youths had spent a significant part of their childhood/youth in the US, which had equipped them with particular frames of reference through which they interpreted their experiences in Senegal.

\section{Seeing Islamic education in Senegal through young ‘American' eyes}

The young people in my research experienced their visits/stays in Senegal as simultaneously exciting and unsettling, echoing the findings of other researchers (Tiilikainen 2011; Zeitlyn 2015; see also Abotsi n.d.; Sancho 2018 in this special issue). Especially the younger children among my respondents usually appreciated the freedom to go visit relatives and friends, and to play outside. At the same time, complaints about the food, heat, noise, pollution, and 'indiscipline' in traffic and with respect to littering were omnipresent in my conversations with children and youths raised in Western settings. Some youths - notably those who had been returned to Senegal against their will, and sometimes even without their knowledge ${ }^{7}$ - declared to outright 'hate' Senegal.

\footnotetext{
${ }^{7}$ While these youths had been told that they were going on vacation to Senegal, their parents intended to leave them there for longer.
} 
Yet, even the most disgruntled and discontented teenagers acknowledged to some extent that Senegal could be wholesome, notably in terms of religion. When I asked my teenage respondents how they would proceed if they had children themselves one day, most conceded that sending them to Senegal was a good idea, not least to learn about their religion. The young people appreciated almost without exception the opportunity to acquire new religious knowledge, ranging from basic notions of Islamic eschatology, to the intricacies of performing ablutions (ritual cleansing) and prayers. Not all of them had been practising Muslims before. Coming to Senegal changed this in most cases, not least because the young people were taught about the other-worldly consequences of their worldly actions. Abdoul (16 years old), for example, explained that in the US,

- I didn't believe in anything. They used to force me to pray and stuff like that.

- And what made you change?

- When I came here, when I learned about, if I die, what's gonna happen, stuff like that.

At the same time, being in Senegal took off the young people's back the pressures of having to stand one's ground as part of a vilified minority against an overwhelmingly deprecatory environment. 14-year-old Abidine put it the following way:

- You know ISIS, ... they think ISIS is Muslim, and that's what Muslim people do, terrorism and stuff. So when they see a Muslim, they get scared and stuff.

- $\quad$ But it's ignorance! And here, is it easier to be Muslim here?

- Yeah! Senegal, everybody - mostly. I'd say I'm Muslim here with no problem, cause here, it's nothing different, everybody is ... you could be anything you want.

While most young people appreciated being in a Muslim-majority environment where they were not singled out as 'other', there are important nuances to be highlighted. Some of the girls I interviewed for example wore the hijab both in the US and in Senegal. Interestingly, this placed 
them in a minority position in both places. While there are important variations in the practice of veiling reflecting 'multiple parameters of identity' (Leblanc 2000, 443), including ethnicity and socio-economic status, the general trend in Dakar is that older women cover their hair when they move in public spaces. Younger women, on the other hand, including married women, often don't or only occasionally. Most women who do consistently wear a hijab (closed under the chin and covering neck and shoulders), identify with the 'Sunni' (or reformist) current, which is minoritarian in overwhelmingly Sufi Senegal. ${ }^{8}$ There have been recurrent tensions between these two currents of thought. Girls and women - who can easily be identified as 'Sunni' by their hijab - are often at the receiving end of these conflicts. One American-raised girl (17 years) for example told me how, in terms of religion, being in Senegal did not feel that different from being in the US to her (even though she enjoyed seeing mosques dotting the landscape): as a hijabi, she was still a minority, and subject to critical commentary by cousins who told her that she was too young to wear a hijab (cf. Zeitlyn 2015, 144, whose young British Bangladeshi respondent found that 'wearing a headscarf was most problematic when she visited her well-educated middle-class family in Bangladesh').

What I have described so far are mixed feelings about Senegal, yet a general appreciation of living in a majority-Muslim environment, even though this feeling is to some extent refracted

\footnotetext{
${ }^{8}$ I have decided to use the term 'Sunni' here as this is how most people referred to themselves, rather than using the more loaded exonyms 'Salafi' or, in Senegalese parlance, 'Ibadou'. Most Sufi Muslims would of course also claim to be following the Sunnah of Prophet Mohammed. According to the Pew Research Center, 92\% of Senegalese Muslims say they belong to a Sufi order $(2012,31)$. Admittedly, some young women wear the hijab (occasionally) without adopting a reformist orientation. To some extent, the hijab has become a fashion statement, indexing, because of its association with the Arab world, a certain cosmopolitanism.
} 
by differences in gender and religious orientation. I now turn to instances when the young people in my research evaluated Islamic practice in Senegal critically, corroborating the findings of other authors (Bolognani 2014; Zeitlyn 2015) that homeland visits may also to some extent widen cultural and religious divides. In my research, diaspora youths commented unfavourably on Islam and Islamic educational practices in Senegal, mobilising normative frames of reference that were apparently 'American' in origin. However, this was mostly done in an effort to reclaim autonomy from elders who laid claim to the prerogative of religious interpretation. ${ }^{9}$ This highlights the importance of paying attention to the wider social dynamics of 'homeland' visits, including intergenerational power dynamics and parental disciplinary projects (cf. the arguments made by Abotsi n.d.; and Sancho 2018 in this special issue).

Several of my young respondents found that people in Senegal were mixing 'culture' and 'religion'. Daouda (14 years old) for example explained that in his view,

in Senegal, people, they change the religion kind of. Because they have the animists, and the Christian beliefs before, and they kind of added it again with Islam. ${ }^{10}$

Ousmane (18 years old) argued that notably older people were guilty of mixing culture and religion, claiming that they would say things that are not actually mentioned in the Qur'an,

\footnotetext{
${ }^{9}$ When my respondents commented on the religious practice of their Senegalese age-mates, it was mostly to state that they were less pious than they made people believe (especially the girls), which bespeaks a certain desire to not be regarded as the only youths with religious 'shortcomings'.

${ }^{10}$ The history of Christianity in Senegal is of course much shorter than that of Islam, which arrived in the region in the $11^{\text {th }}$ century. The first Europeans arrived on the West African coast at the end of the $15^{\text {th }}$ century, but most busied themselves with the slave trader rather than with evangelization. Missionary activity gathered pace mostly in the $19^{\text {th }}$ century.
} 
but they base it on their culture and say, that's not good, you shouldn't be doing it, and it's not even mentioned in the Qur'an.

Particularly in cases where Islam was mobilised to regulate their own behaviour, the young people in my research were critical of the religious justifications presented to them, especially if these targeted behaviour that, in their experience, had passed as normal until then. One particularly contentious issue was hairstyling. In Senegal, most boys and young men wear their hair shortly cropped, and both longer hair and elaborate hairstyling are reserved for girls and women. ${ }^{11}$ Several of the American-raised male youths I met during my research had grown accustomed to fashionable hairstyling in the US, which included both longer hair and more sophisticated cuts. When they showed up at their Islamic school with such hairstyles, tensions resulted with the school administration that insisted on close-cropped hair. Mohammed (17 years old) recounted his experience:

they told me I gotta cut off my hair, and I was like: 'why do I have to cut off my hair, it's just a hairstyle!' And then they started talking about, ahm, why it's illegal in Islam to have a hairstyle like, you cut the sides, you leave the sides [middle?], and I never actually heard somebody tell me that until I came here. And then it made me feel weird, I was like, ok then, imma just gonna cut it up. Because, when like, when you're in a place, you just have to - it's just easier to just follow the rules and not try to bring your own [rules], cause they're gonna win.

${ }^{11}$ Women's use of hair attachments spark a certain controversy though, with stricter Muslims looking upon it critically, arguing that 'adding' something to the body amounts to saying that Allah has created imperfect bodies. There is also a prominent exception to the rule of short hair for men. Socalled Baye Fall, disciples of Mouride Cheikh Ibrahima Fall, a contemporary of Cheikh Amadou Bamba, commonly wear dreadlocks - though this meets with some disapproval from Muslims of other religious orientations. 
In the case described here, the youth remained sceptical whether Islam really required him to have close-cropped hair, but eventually gave in because he did not want to exacerbate tensions with the school administration. The school administration's insistence on short hair did not resonate with his prior experiences, and thus he struggled to give it credit. In a similar way, the young people in my research commented critically also on other practices. For example, the beatings frequently dealt out in Islamic schools (as well as private households and secular state schools) in Senegal as a form of discipline were a frequent object of critical commentary. Arguably, many parents - and even children ${ }^{12}$ - across West Africa consider disciplining involving physical punishments an essential part of child-rearing and forming appropriately 'educated persons'. As Last $(2000,376)$ writes about northern Nigeria, without 'external shaping' in the form of discipline and physical hardship 'a child is scarcely human, and certainly not a proper Muslim'. Such an ideology underpins the harsh physical punishments dealt out in Qur'anic schools across West Africa (Ware 2014; Hoechner 2018).

Conversely, in the US, child protection laws forbid harsh physical punishments, and children are encouraged to report these to the authorities. Having grown up in the US, the American-raised youths in my research considered beatings critically as 'abuse' and 'violence' rather than legitimate and even 'necessary' disciplining (cf. Abotsi's paper in this special issue on British-raised youngsters' discontent about the strict disciplinary regime of their Ghanaian school). Daouda (14 years old) for example stated about his experience in a classical Qur'anic school that:

\footnotetext{
${ }^{12}$ I gave English and French lessons in Qur'anic schools in Senegal and Nigeria, and on various occasions, my students told me that if I wanted my class to be quiet, I would have to beat them.
} 
they use, like, violence to press their views, and I don't really like that. Just teach someone through, like, words, and not through violence. If you use violence, they're [the students] probably not gonna listen to it, so - or if they do, they're not really gonna believe in [it]... ${ }^{13}$

A last example that illustrates how the young people in my research mobilized normative frameworks of 'Western' origin to make sense of the realities they encountered in Senegal concerns the gender segregation commonly practiced in Islamic boarding schools in Senegal, with boys and girls usually studying in separate facilities (cf. Abotsi's description in this special issue of how her British-Ghanaian respondents mobilised children's rights discourses to criticise Ghanaian educational practices). Many aspects of daily life in Senegal, starting with the division of labour within the household, are highly gendered, and even though the exact contours of gendered differences may be the subject of discussion and negotiation (e.g. what kind of work contributions can be expected from males within the household), it is usually taken as a given that differences are an objective reality and legitimate basis for differential treatment. I have never heard anyone from Senegal commenting on gender segregation in Islamic schools in negative terms. Even though not all Islamic schools separate students by gender, most Senegalese do not seem to take issue with schools that do. Mohammed, a mostly American-raised youth (17 years), on the other hand, commented on this critically:

I think separating is kind of sexist! I mean religion shouldn't mean like you gotta separate people. People could still be together and not, like - they think like if you mix them, there's gonna be sin or whatever. But I think like the more people socialise with each other, the better. Cause if you separate people, they won't know how to share ideas.

\footnotetext{
${ }^{13}$ These critical comments were made outside of the Islamic schools where the beatings had taken place and in retrospect.
} 
When passing critical judgement on particular 'Senegalese' religious practices, the young people in my research thus mobilized normative frames of reference of apparently 'American' origin, even though they found themselves in Senegal at the time and had in many cases been there already for several years. That the disciplinary projects of parents and elders were particularly likely to be evaluated through 'American' lenses highlights again the importance of paying attention to the social dynamics of homeland visits/stays.

\section{Conclusion}

Homeland visits and stays have only recently began to receive attention within the growing literature on the religious beliefs and practices of 'second generation' Muslims in Western contexts, just as African Muslims have largely been neglected within this emerging field. Drawing on data collected among Senegalese migrants and their children in Senegal and the US, this paper adds to the nascent scholarship exploring young Muslims' experiences of return mobility.

I explore the longer-term consequences of homeland returns for young people's future trajectories elsewhere in greater depth (Hoechner forthcoming). Suffice it to say here that such returns not only strengthen young people's self-confidence as Africans and blacks, but also produce new sets of vulnerabilities as young people may struggle to (re-)adjust to the social environment and disciplinary regime of the US and lack the English language skills to do well in school and college. As described in this paper, in terms of religion, visits to and stays in Senegal allowed the young people in my research to develop a new and overall more serene relationship with Islam, not least because they found themselves in an environment where being Muslim attracts no disdain and indeed connotes positively. This did not, of course, mean that their prior 
experiences and 'American' frames of reference became completely obsolete. Returning to Senegal is an ambivalent experience for young people who have spent most of their previous lives in the US. It requires adjustments on various levels, ranging from the mundane details of everyday life to wider epistemological / eschatological ideas. Young people are not blackboards whose contents can be erased and rewritten at will. Instead, they draw on their previous experiences and normative frameworks as they critically appraise the practices they observe and treatments they receive in Senegal. The young people in this study were particularly likely to pass critical judgement on 'Senegalese' religious / educational practices in situations when (presumably) religious norms were mobilised to regulate their behaviour and to discipline them. This highlights that homeland visits do not necessarily produce complete agreement between parents, teachers and youths about what exactly an ideal 'educated person' is, and what appropriate strategies are for producing it.

Finally, this paper pointed to the changes taking place within Senegal's educational landscape as new educational offers emerge to cater to the transnationally mobile. This further complicates ideas about the transmission of religious identities and orientations across generations and transnational space. In the current context of growing Islamophobia and increasingly aggressive secularism in Western countries, many immigrant parents in the West are hard-pressed to bring up their children as practicing and self-respecting Muslims. It would not come as a surprise if Muslim homelands and the educational offers emerging in these were to gain in importance in the future as places where migrants educate their children, adding further urgency to the exploration of the dynamics described in this paper.

Acknowledgements 
Financial support from the Research Foundation - Flanders (FWO) and the Philippe Wiener - Maurice Anspach Foundation (FWA) is gratefully acknowledged. 


\section{Bibliography}

Abotsi, Emma. n.d. 'Negotiating the 'Ghanaian' Way of Schooling: Transnational Migration and the Construction of the Educated Person among British-Ghanaian Families.”

_. 2018. “"Ghana Is an Eye Opener': Enlightened Personhood and Transnational Education among British-Ghanaians." University of Oxford.

Babou, Cheikh Anta. n.d. "Making Room for Islam in the West: Senegalese Muslims in Europe and North America." Accessed January 9, 2015. http://www.ascleiden.nl/news/seminarmaking-room-islam-west-senegalese-muslims-europe-and-north-america.

Bledsoe, Caroline, and Papa Sow. 2011. "Back to Africa: Second Chances for the Children of West African Immigrants." Journal of Marriage and Family 73 (4): 747-62.

Bolognani, Marta. 2014. "Visits to the Country of Origin: How Second- Generation British Pakistanis Shape Transnational Identity and Maintain Power Asymmetries." Global Networks 14 (1): 103-20.

Carling, Jørgen, and Silje Vatne Pettersen. 2014. "Return Migration Intentions in the IntegrationTransnationalism Matrix." International Migration 52 (6): 13-30.

Cesari, Jocelyne. 2002. "Islam in France: the shaping of a religious minority." In Muslims in the West. From Sojourners to Citizens, edited by Yvonne Yazbeck Haddad, 36-51. Oxford: Oxford University Press.

Coe, Cati. 2014. The Scattered Family. Parenting, African Migrans, and Global Inequality. Chicago \& London: University of Chicago Press.

Coe, Cati, and Serah Shani. 2015. "Cultural Capital and Transnational Parenting: The Case of Ghanaian Migrants in the United States." Harvard Educational Review 85 (4): 562-586,683.

Dia, Hamidou. 2016. "Pratiques de Scolarisation de Jeunes Français Au Sénégal. La Construction de l'excellence Par Le Pays Des 'Ancêtres." Cahiers d'études Africaines 1 (221): 199-218.

Erdal, Marta Bivand, Anum Amjad, Qamar Zaman Bodla, and Asma Rubab. 2016. “Going Back to Pakistan for Education? The Interplay of Return Mobilities, Education, and Transnational Living." Population, Space and Place 22 (8): 836-48.

Grysole, Amélie. 2018. "Private School Investments and Inequalities: Negotiating the Future in Transnational Dakar." Africa 88 (4).

Haddad, Yvonne Y., Farid Senzai, and Jane I. Smith. 2009. Educating the Muslims of America. Oxford: Oxford University Press. 
Hoechner, Hannah. 2017. "Islamic Education and the 'Diaspora': Religious Schooling for Senegalese Migrants' Children." In New Directions in the Study of Islamic Scholarship in Africa, edited by Ousmane Kane. Boston.

. 2018. Quranic Schools in Northern Nigeria: Everyday Experiences of Youth, Faith, and Poverty. Cambridge: Cambridge University Press.

. Forthcoming. "Mobility, social reproduction and triple minority status: young Senegalese-Americans' experiences of growing up transnationally." Children's Geographies.

Kane, Ousmane. 2011. The Homeland Is the Arena. Oxford: Oxford University Press.

Kea, Pamela. 2016. "Photography and Technologies of Care: Migrants in Britain and Their Children in the Gambia." In Affective Circuits. African Migrations to Europe and the Pursuit of Social Regenerations, edited by Jennifer Cole and Christian Groes, 78-100. London: University of Chicago Press.

Kea, Pamela, and Katrin Maier. 2017. "Challenging Global Geographies of Power: Sending Children Back to Nigeria from the United Kingdom for Education." Comparative Studies in Society and History 59 (4): 818-45.

King, Russell, and Anastasia Christou. 2011. "Of Counter-Diaspora and Reverse Transnationalism: Return Mobilities to and from the Ancestral Homeland." Mobilities 6 (4): 451-66.

Last, Murray. 2000. "Children and the Experience of Violence: Contrasting Cultures of Punishment in Northern Nigeria." Africa 70 (3): 359-93.

Leblanc, Marie Nathalie. 2000. "Versioning Womanhood and Muslimhood: 'Fashion' and the Life Course in Contemporary Bouaké, Côte d'Ivoire.” Africa 70 (3): 442-81.

Levinson, Bradley A, and Dorothy C Holland. 1996. "The Cultural Production of the Educated Person: An Introduction." In The Cultural Production of the Educated Person. Critical Ethnographies of Schooling and Local Practice, edited by Bradley A Levinson, Douglas E Foley, and Dorothy C Holland. Albany, NY: State University of New York Press.

Levitt, Peggy. 2003. "'You Know, Abraham Was Really the First Immigrant': Religion and Transnational Migration.” International Migration Review 37 (3): 847-73.

Levitt, Peggy, Melissa D Barnett, and Nancy A Khalil. 2011. "Learning to Pray: Religious Socialization across Generations and Borders." In Mobile Bodies, Mobile Souls. Family, Religion and Migration in a Global World, edited by Mikkel Rytter and Karen Fog Olwig, 139-60. Aarhus: Aarhus University Press.

Levitt, Peggy, Kristen Lucken, and Melissa Barnett. 2011. "Beyond Home and Return: Negotiating Religious Identity across Time and Space through the Prism of the American Experience.” Mobilities 6 (4): 467-82. 
Lindley, Anna. 2008. "Transnational Connections and Rducation in the Somali Context." Journal of Eastern African Studies 2 (3): 401-14.

Mandaville, Peter. 2007. "Islamic Education in Britain: Approaches to Religious Knowledge in a Pluralistic Society." In Schooling Islam. The Culture and Politics of Modern Muslim Education, edited by Robert W Hefner and Muhammed Qasim Zaman. Princeton: Princeton University Press.

Oeppen, Ceri. 2013. “A Stranger at 'Home': Interactions between Transnational Return Visits and Integration for Afghan-American Professionals." Global Networks 13 (2): 261-78.

Pew Research Center. 2012. "The World's Muslims: Unity and Diversity.” Washington DC. http://www.pewforum.org/files/2012/08/the-worlds-muslims-full-report.pdf.

Razy, Élodie. 2006. “De Quelques 'Retours Soninké’ Aux Différents Âges de La Vie. Circulations Entre La France et Le Mali.” Journal Des Anthropologues 106-107 (2006).

Reisel, Liza, Anja Bredal, and Hilde Lidén. 2018. "Transnational Schooling among Children of Immigrants in Norway: The Significance of Islam.” In Growing Up Muslim in Europe and the United States, edited by Mehdi Bozorgmehr and Philip Kasinitz, 153-71. Palgrave Macmillan.

Rytter, Mikkel. 2010. "A Sunbeam of Hope: Negotiations of Identity and Belonging among Pakistanis in Denmark." Journal of Ethnic and Migration Studies 36 (4): 599-617.

Sancho, David. 2018. "Exposed to Dubai: Education, Identity, and Mobility among Young Indian Migrants in the Golf."

Tiilikainen, Marja. 2011. "Failed Diaspora: Experiences of Dhaqan Celis and Mentally Ill Returnees in Somaliland.” Nordic Journal of African Studies 20 (1): 71-89.

Timera, Mahamet. 2002. "Righteous or Rebellious? Social Trajectory of Sahelian Youth in France." In The Transnational Family. New European Frontiers and Global Networks, edited by Deborah Bryceson and Ulla Vuorela, 147-54. Oxford: Berg.

Timmerman, Christiane, Els Vanderwaeren, and Maurice Crul. 2003. "The second generation in Belgium.” International Migration Review 37(4): 1065-1090.

van Geel, Joan and Valentina Mazzucato. 2018. "Conceptualising youth mobility trajectories: thinking beyond conventional categories." Journal of Ethnic and Migration Studies, 44 (13): 2144-2162.

Voas, David, and Fenella Fleischmann. 2012. "Islam moves west: Religious change in the first and second generations." Annual Review of Sociology 38: 525-545.

Ware, Rudolph. 2014. The Walking Qur'an. Islamic Education, Embodied Knowledge, and History in West Africa. Chapel Hill: University of North Carolina Press.

Zeitlyn, Benjamin. 2014. "Making Sense of the Smell of Bangladesh." Childhood 21 (2): 17589. 
-2015. Transnational Childhoods. British Bangladeshis, Identities and Social Change. Basingstoke \& New York: Palgrave Macmillan.

Zine, Jasmin. 2008. Canadian Islamic Schools. Unravelling the Politics of Faith, Gender, Knowledge, and Identity. Toronto: University of Toronto Press. 